\title{
Aortic valve calcification - the role of inflammation and fibrosis
}

\author{
K Pissaridi ${ }^{1}$, V Dritsa ${ }^{1}$, J Anastassopoulou ${ }^{1}$, E Koutoulakis ${ }^{2}$, I Mamarelis ${ }^{3}$, Chr Kotoulas ${ }^{4 *}$ \\ From 23rd World Congress of the World Society of Cardio-Thoracic Surgeons \\ Split, Croatia. 12-15 September 2013
}

\section{Background}

Pathogenesis of aortic valve calcificationis a multifunctional processassociated with various risk factors, while heart valve replacement is the only established treatment. Unfortunately, the real mechanism of the valve calcification remains still unknown. Herewith, we investigate the changes in molecular levelof aortic valve tissues in order to characterize the mineral deposits and understand the mechanism of aortic valve mineralization and stenosis.

\section{Methods}

30 aortic valves samples of patients (65-80 years), who underwent surgical aortic valve replacement due to aortic valve stenosis. A Nicolet 6700 thermoscientific spectrometer was used to record the infrared (FT-IR) spectra. The aortic valve surfaces were studied with Scanning Electron Microscopy (SEM-EDX), without any coating of the samples.

\section{Results}

The infrared spectra showed intensity changes and shifts of characteristic bands concerning the peroxidation of lipids suggesting inflammation character of stenosis. The proteins and collagen changed their $\alpha$-helix to random one.The mineral deposits were consistent of calcium phosphates, $\mathrm{CaHPO}_{4}$ and amorphous hydroxyapatite, depending on the chemical factors of the cells' microenvironment. In the case of SEM showed that the crosslink bonds of collagen are the targetingsites where the minerals start the deposition.

\section{Conclusions}

The characteristic FT-IR absorption bands of calcified stenotic aortic valves showed hyperoxidation of membranes

\footnotetext{
* Correspondence: chrkotoulas@gmail.com

${ }^{4}$ Department of Cardiac Surgery, laso General Hospital of Athens, Greece

Full list of author information is available at the end of the article
}

(a pro-inflammation stage), while the mineral deposits were consistent of low crystallinity biological $\mathrm{HA}\left(\mathrm{Ca}_{10}\right.$ $\left.\left(\mathrm{PO}_{4}\right)_{6}(\mathrm{OH})_{2}\right), \mathrm{Ca}_{2} \mathrm{HPO}_{4}$ and calcium phosphate of phospholipoprotein fragments. SEM-EDX data show substitution of calcium cations from magnesium cations leading to amorphous hydroxyapatites. This finding suggested that magnesium supplements could prevent the re-calcification of the implants.

\section{Authors' details}

${ }^{1}$ Chemical Engineering Department, Radiation Chemistry \& Biospectroscopy, National Technical University of Athens, Greece. ${ }^{2}$ Department of Cardiology, NIMTS Veteran Hospital of Athens, Greece. ${ }^{3}$ Department of Cardiology, 401 Army General Hospital of Athens, Greece. ${ }^{4}$ Department of Cardiac Surgery, laso General Hospital of Athens, Greece.

Published: 11 September 2013

doi:10.1186/1749-8090-8-S1-O32

Cite this article as: Pissaridi et al: Aortic valve calcification - the role of inflammation and fibrosis. Journal of Cardiothoracic Surgery 2013 8(Suppl 1):O32.
Submit your next manuscript to BioMed Central and take full advantage of:

- Convenient online submission

- Thorough peer review

- No space constraints or color figure charges

- Immediate publication on acceptance

- Inclusion in PubMed, CAS, Scopus and Google Scholar

- Research which is freely available for redistribution

Submit your manuscript at www.biomedcentral.com/submit
() Biomed Central

\section{() Biomed Central}

